\title{
The Role of Muslim Ummah in Mutidimensional Societies in The Light of Seerah of The Holy Prophet (PBUH)
}

\author{
Dr. Farhat Aziz ${ }^{1}$ \\ Dr. Syed Naeem Badshah ${ }^{2}$ \\ Zishan Ahmad ${ }^{3}$
}

ISSN (P) 2664-0031 (E) 2664-0023

Received: March 19,2021

DOI: https://doi.org/10.37605/fahmiislam.v4i1.234

Accepted: March 22, 2021

Published: June 30,2021

\begin{abstract}
Islam is the only religion that guides man in every sphere of life. From birth to death, all the needs and problems of life have been explained in it. In order to be presented as an entity in which is comprehensiveness, there will be only a model of excellence in the form of last prophet Muhammad (PBUH). His (PBUH) perfection is declared in the Holy Qur'an. The Sunnah of the Prophet $(\mathrm{PBUH})$ presented every guidance of the Book of Allah to mankind in the form of action. Whether it is political, economic, social, individual, collective, and any other all aspects of life. The transparent life of the Holy Prophet (PBUH) is invaluable for human society. For the formation of a better human society and the well-being is necessary for every individual to perform the role model in Multidimensional society to contribute in promoting the good environment as Muslim Ummah in the world. Through these sorts of continuous practices, the society comes into being in which makes possible the protection of the lives, honor and property of every individual.
\end{abstract}

Keywords: Role, Muslim Ummah, Multidimensional, societies, perspective, Seerah, Holy Prophet

\section{Introduction}

From the first humans, Hazrat Adam and Eve to the long journey of humankind, numerous and diverse societies emerged, which were different from each other because of their particular beliefs and rituals. Egyptian, Greek, Hindi, Roman and Iranian civilizations remain prominent in this

\footnotetext{
1 Associate Professor, Lahore College for Women University, Lahore.

2 Chairman, Islamic Studies, The University of Agriculture Peshawar.

3 PhD Scholar in Qurtuba University of Science \& Information Technology, Peshawar.
} 
social and cultural journey. At the time of appearing Islam, all these societies had lost their social influence and had fallen religiously, socially and spiritually. Arabian society was divided into several tribes with diverse religions, the society was united under the belief of one God, one messenger, and one Qur'an, and for centuries the duty of leading and guiding the whole world. Subsequently, due to away from the Qur'an, negligence, luxury, and convenience, it began to fall. However, Islam is still the second-largest religion in the world in terms of numbers. The Muslim world, whether in the Middle East or in most South Asian countries, suffered an economic crisis after their political independence. That is why people from Asian countries, whether Muslim or non-Muslim, turned to the USA and European countries for employment. Most young people went to the United States and Europe in pursuit of education and settled there. Over the past two decades, the latest technology has resulted in media and scientific developments, because of this, the distances between societies at the global level are narrowing. The influence of Western countries in Asian countries and the mass migration of people from Asian countries to Western countries have led to the staining of multinational societies. India is among the top Asian countries in these multi-ethnic societies. There are still 120 million Muslims inhabited. Other religions, such as Sikhism, Jainism, and Buddhism, are in addition. Apart from this, Burma, Sri Lanka, Bangladesh, and Indonesia are also the manifestations of a propagandistic society. In Western society, the United States and Australia, as well as in many countries of Europe such as Britain, France, Germany, Italy, and the Netherlands are mostly populated of Christians, Muslims, Jews, and other religions inhabitants. A significant number of people have taken the form of a pluralistic society.

\section{Statement of Problem}

In this paper, the concept of multidimensional societies' and role of Muslim Ummah has been described. The cultural instability that has led to the formation of a global society and multi-dimensional societies have emerged as a result of modern technology and high-speed media which is a common concern for humanity. It is also evident from the fact that in contrast to other minority religions such as Hinduism and Sikhism, Islam is a religion that is growing rapidly in western societies. The growing influence of Islam has left Western scholars and leaders worried. Demographics of religious, linguistic and racial prejudice have created very difficult conditions for Muslims in these societies. As a result, they have to deal with a variety of issues, religiously, socially, politically and economically. In this way, the entire Muslim community is obliged to take the lead in dealing with these problems. Thus, today's Muslims are committed to enduring cultural devotion to religion by taking a leading role in modern technocratic society 
through the adherence to religion, commitment to true religion, the survival of religious identity, religious tolerance, and creativity by eliminating civilizational clashes can create a well-managed and community-based welfare society.

\section{Literature Review}

The following books and articles are directly related to literature review on the concept of peace in Islam. i.e. Sarwat Sulat, Dunya mein Muslim Aqliatien, Musa Khan Jalal Zai, Musalman Aqliatien charun briazmun mein, Muslims are projected to increase as a share of Europe's population - even with no future migration, Masood Abdali, America mein Islamophobia aur Tashadud ki Lehar, Iftikhar Gillani, Azadi Raye , Magrabi Tazadat aur Mulim etc. Although a lot of have been written on this topic but describing all will prolong the discussion.

\section{Research Questions}

1. What is the purpose of Islamic beliefs and practices?

2. Why Islamic teachings need to highlight in present era?

3. How Seerah of Holy Prophet (PBUH) can be implemented and the role of every Muslim need to describe in multidimensional society?

\section{Research Objectives}

1. To identify the purpose of Islam in Multi dimensional societies.

2. To explain and highlight the Seerah of Holy Prophet (PBUH) for the contributions of Muslim Ummah in modern time.

3. To promote the awareness about the implementation of Islamic teachings in the present world.

\section{Research Scope}

Although a lot of articles and books have been written on the concept of Islam but my specification of research would be about the role of Muslim Ummah in Multidimensional societies In the light of Seerah Holy Prophet (PBUH). To clarify the different aspects of Seerah and the role of Muslims, I will focus on Qur'an, Sunnah and basic Islamic traditions.

\section{Research Methodology}

In this research the widely applied methodology will be 'ANALYSIS' about the role of Muslim Ummah in Multidimensional societies, In the light of 
Seerah Holy Prophet (PBUH). The famous and authentic books \& articles will be analyzed compared about the topic.

The twenty-first century is the most important in the United States with regard to the religion of Islam. "Muslims settled in the United States on a regular basis. During this period, many Muslims migrated from Turkey, Lebanon, Palestine, Syria, Yugoslavia, Russia, Albania and Poland."1 Today, a large number of Muslims reside in all states of the USA. "American Muslims include African, Arabic, Hindi, Pakistani, European, Turkish, Iranian and Afghan ethnic people living in New York, Boston, Washington, and Chicago."2 Also, Muslim immigrants are living in large numbers in the UAE. Islam is the second-largest religion after Christianity in Europe. According to a report by PEW Research Center, there are 5,720,000 Muslims in France, 4,950,000 in Germany, 4,130,000 in Britain, 2,870,000 in Italy, 1, 20, 000 in the Netherlands and 1,180,000 in Spain. Islam is the fastest-growing religion in the world more than twice as fast as the overall global population. Between 2015 and 2016 the world's inhabitants are expected to by $32 \%$ but the Muslim population is forecast to grow by $70 \%$. Even though Christian will also outgrow, the general population over that period, with an increase of $34 \%$ forecast mainly thanks to population growth in sub-Saharan, Africa, and Christianity is likely to lose its spot in the world religion league table to Islam by the middle of this county. ${ }^{3}$

Australia is also a multi-faceted society where Christian, Hindu, Muslim, Sikh and Buddhist followers exist in the minority. Australia is a multi-faith society. The 2016 causes show that, while the mix of belief has changed over the years, Australia remains a pretty religious place. ${ }^{4}$

The formation of a universal society and multi-faceted societies that have emerged as a result of contemporary electronic communication systems has given rise to a new cultural tragedy. The desire of the colonial system to overcome the cultural superiority of the United States and the West, and the pursuit of technological mastery, has created an inescapable gulf between human beings. The United States and other Western powers trying to dominate the global colonial system must also look at the perspectives of Western intellectuals whose real point of view is that "The world is not going to become western. Neither the west nor the rest is going to become this world. Diversity is here to stay." 5

That is, the world is not going to fall into the Western civilization, neither the West nor the rest of the world is becoming the world. The future, however, is diverse and multifaceted. Unlike other minority religions, the rapidly increasing influence of Islam in Western society has confused the Western powers. Under the guise of the Nine-Eleven incident, Muslims are 
labeled a terrorist and discriminated against by different factions. Today, Muslims are facing racism, prejudice, and injustice in all walks of life in India, America and Europe. Due to this, very complex and serious problems have arisen. These issues are religious, social, political and economic. Whose details are relevant to the situation of these multi-ethnic - societies.

\section{Religious Issues:}

Muslims face two types of religious problems in these multi-ethnic communities of America and Europe. One is as Muslims, to adopt practices that are distant from Western, and secondly, those who truly practice religion have to face criticism. ${ }^{6}$

As far as the first issue is concerned, the Muslim community has been lacking in religious education because of its lack of religion, they feel doubts in their religion, so programs of Western scholars are broadcast on the media which revitalize the Qur'anic Ideas prove to be subject to the modern interpretation of ideas. Dr. Katani a Moroccan Arab, himself, mentions in his book "Muslims in Europe and America" the religious animosity of the Arabs and the Western way of life with great regret.

"How many Muslims have been alienated from Arab religion through the two dietitian breeds that some of them are unaware of the basic principles of Islam and cannot read rightly to bismillah. As a result of marriage, new generations are becoming Christians, the same is true of the Arabs in Argentina whose number is three million."7

The second type of religious issues is related to Muslims who adhere to Islam and maintain their religious identity. They are accused of terrorism and religious extremism. Particularly in the United States and the West after 9/11, there was a strong upheaval that Muslims were terrorists. Jews and Christians do not shy away from any action against Islam and blasphemy. According to Masood Abdali: "When the tragedy started in September, a poisonous campaign against the non-Muslims started. Sikhs from some places were attacked because of the turban and long beards. That is why extremists are targeting them, While female veil is considered a Muslim religious symbol over there."

One of the most disturbing and condemnatory acts by the West is the publishing of abusive sketches that have offended the spirit of the entire world. The Dutch Member of Parliament Geert Wilder announced the contest for the abusive sketches. Wilde said in his written message that he had announced the termination of the contest in response to threats of murder and possible reaction from the Muslims. That spread around the 
world on this issue, before the Dutch government issued a written document to stop displaying abusive sketches. In India, too, many people are trying to provoke Muslims by using derogatory words against Prophet Mohammad and his family under the guise of free speech. We were trained to provoke the feelings of Muslims. ${ }^{9}$

According to a July 3 report, an eye specialist wearing a mask outside the mosque in Texas city Houstonof the US state was attacked by firing three unknown persons. Some unidentified people were also attacked by outside a mosque on the boy in the United States and arrested a man. ${ }^{10}$ In Europe, France is the country where most Muslims are settled. Marian Lopen heads the National Front, the anti-Muslim party over there. He stated in 2010: When Muslims worship on the streets I think that Nazi Germans have occupied France again. It is often attacked by Muslims. Its long-standing demand has been to ban the wearing of burqas in France and the arrival of Muslim refugees. ${ }^{11}$

\section{Social Issues}

Muslim families living in Western societies face many social and moral issues. Some are born because of the non-Islamic, the alien environment and some because of their minority there. Registration issues for Muslims in the United States have taken a serious turn. Because every Muslim is viewed with suspicion and scandalously investigated as if he were in the US for terrorism.

The hate crime against Muslims increased after 2001, and then the series continued. The US Investigator FBI reported that the crime rate was 107 percent in the United States around 2009, which was based on hate crimes. It has increased to 140 percent in 2010 almost in 10 years. ${ }^{12}$

Britain's leading newspaper "Independent" published a report on the rise of discrimination against Muslim students among British educators. According to a weekly magazine, students at British schools are promoting a wave of prejudice and hatred against Islam and Muslims in British schools. A school in Oxford shire, A ten-year-old Muslim student with a good academic record suffered a lot of anxiety and distress when participating in a debate that began in the historical period, the teacher said. Use shirts with dirty sketches. The kid says that after the end of the parade, a group of older boys stopped me and called me "terrorist" and "purity". ${ }^{13}$

There is a distinct identity of Islamic civilization that is distinguished from all other civilizations. Muslims in happiness and sadness have their own Islamist ways, but Muslims living in Europe and America are also 
vulnerable to these opportunities. Muslim babies are born in hospitals. But according to the bodily rules in the shroud burial, Meat is immediately brought to earth Dose funeral home tied and makeup is done on the face of the deceased. So that the survivors do not suffer shock. The laws of child custody and abortion in the case of divorce are radically different from Islamic laws, but American Muslims have compulsively adopted it. They saw an American in a coffin. He was tied and makeup did it. Christians also came and kissed Meth. ${ }^{14}$

After the Paris attacks, they are living here in a climate of hysteria and disgust that has not been seen even after 9/11. A mosque was burned down in Virginia after the Paris Palace, while hateful words were also posted on its walls. ${ }^{15}$

From the above facts, it is clear that out of the 05 crores Muslims in the world who practice Islamic traditions, they face many problems, from Australia to the United States and Argentina. During their day-to-day tasks, they are treated with a hateful demeanor. Even extremists attack them simply because they are wearing Islamic clothes. This situation has erected a wall between the Islamic and Western religions. In order to bridge that, the philosophers of both civilizations have to find a unified mechanism.

\section{Political Issues}

Who is not aware of the problems of the Muslim minority community living in South Asia? Where Muslims are facing problems in different walks of life. Especially in the political area Muslims are trying to push back. Muslims in India have been somewhat weighed down by politicians. It can be inferred that Ghulam Nabi Azad, the ruling Congress leader and leader of the Opposition in the upper house, recently complained that 'Hindu members of his own party are now feeling hate being invited him to meetings and processions in his circles. In the prime minister's hometown of Gujarat where Prime Minister Narendra Modi had given full force to the BJP last years, workers were formally instructed not to have any Muslim leader on the stage, even from Congress to Gujarat. Ahmed Patel, a powerful leader and political adviser to Sonia Gandhi, had to stay behind. The candidates were told not to go to the polling booths in Muslim polls and would not have long beards and hats in the procession. Gradually they are not considering Muslims citizenship in India. ${ }^{16}$

Regular racism is practiced in Israel. It is clear that the UN agency published a legal study report in last year that Israeli authorities were following a model for territorial integrity in which minorities were expelled and discriminated. ${ }^{17}$ The Communist military government in Burma forcibly 
expelled more than a dozen Muslims from the country without prior notice. In Sri Lanka, Tamil separatists burned several Muslim villages, including tribes. The worst brutal atrocities Muslims at the hands of Indian lobby in Kashmir these days. Some prejudiced theologians, such as Paster Nalliah, have a blatant attitude toward Islamic teachings. "Let us become the slaves of the Islamic Shari'ah by our cross-country, by establishing an independent democratic society and by adopting the Bible." Byzantine Nalliah formed a political party aimed at banning Muslims from coming to Australia."18

US President in his presidential campaign not only spoke against Muslims but also called for stringent laws and banning the entry of Muslims into the United States. Director of the American Arab Anti-Discrimination Committee, said the anti-Muslim situation in the United States is getting more dangerous. The most alarming situation is that never before have fascist intellectuals made such anti-Muslim statements. ${ }^{19}$

According to the report of Hind: Muslims are currently living in the shadow of fear in three EU countries and especially after recent attacks on Paris. Now they are not only openly opposing the Muslims there, but are also involved in the killing and destruction of property by ordinary Muslims. ${ }^{20}$

\section{Economic Issues}

In the mid-twentieth century, when the United States reached the peak of economic growth, Muslims from Arabia, the Middle East, and Asia also turned to the United States and Western countries. But the fact is that these Muslims who settled in the United States and Europe for the sake of peace have always suffered here because of their Islam. The incident of the 9/11 and Paris attacks have raised new issues for Muslims from an economic point of view. "To get a job for Muslims in the United States has to be not as good for two reasons, because of the women hijab, and beards to cause men continuously to quit their jobs." A Muslim woman was used to wear a loose dress. When she expressed her Islam to the employers, the same people who considered her dress fashionable were turned against her and eventually she was answered by her job. ${ }^{21}$ Previously we were getting unpaid and unemployed jobs everywhere, without the green card and work permit. But now the situation is that even the nineteen certified American Muslims born in the United States do not get jobs. As soon as they hear the Islamic name, they do excuse it. ${ }^{22}$ In the US, Muslim youths are arrested on the basis of mere suspicion by educators but after their release, no Company is ready to give them work because their reputation has worsened. Muslim students in the United States have been deported, night and day behind the laboring helpers (FBI). The innocent have been jailed. I was forced to seek refuge. ${ }^{23}$ Terrorist attacks in the name of Islam in Paris have hampered the lives of 
Muslims not only in France but also in other European countries. According to the prestigious Hindustan Report: "Muslims in Europe have developed a fear that their future in this growing environment of intolerance will be not bright as their educational and business activities are being badly affected after the Paris attacks."24

\section{Role of Muslims in the Present Era}

The problems of Western pluralism are very complex and serious. Muslims are not only destined for pluralism in India, the United States, and Europe but Muslim communities also face problems of professional and group dissolution due to the Shi'ite, Sunni, Barelvi, Deobandi, Hanafi and Shafi'i divisions. Which has a negative impact on the younger generation? Nevertheless, the role of the new generation in the success and in rising and decline of any society is very important. Youth are a valuable asset to the future of society. Some of the key attributes are needed to ensure the accuracy of the society and make it comfortable and enjoyable. History has testified that youth has been an important part of the great revolutions that have taken place in the world. The Qur'an clarifies the role of youth with regard to Ashab al Kahf is an important incident in history. Those who declare their rightfulness before the oppressive rulers and protect their faith. The young men who prepared and taught the Prophet (PBUH) were outstanding and talented human beings. In the Hadith of the Prophet $(\mathrm{PBUH})$, the rules regarding the role of young Muslims and their responsibilities are frequently found. Thus, in the light of Islam, ideal propagation societies can create. The role of today's youth is to promote interfaith, religious tolerance, positive thinking and affection, love, gentle striving, and creativity. Family relationships play a key role in tackling the problems of a modern plural society. Today's youth can adapt to the challenge of modern transgender society in light of the following golden principles.

1. Faith: All matters of social life are based on fundamental beliefs. The system of Islamic faith prevails exclusive unity for various sects and different people. Today's youth must strengthen and maintain a relationship with Allah. Allah says:

"Indeed, those who have said, "Our Lord is Allah" and then remained on a right course" 25

A companion of the Prophet came to him. He (PBUH) said, "Say, 'I believe in Allah' and then be steadfast". ${ }^{26}$ In Western post-apartheid society, many Muslims have lost their identity. Therefore, faith is the first basis in such societies to protect their Islamic identity. Syed Abul Hassan Ali Nadvi gave this message to the young people living in the American community in these 
words: "To create faith in yourself, read the Quran and then send a message of religion to the Americans."27

A good example of the perseverance that Islam teaches is seen in the model of excellence of Muhammad (PBUH). When he invites the people of Mecca and faces opposition, resistance and suffering from all sides, even his dear Uncle Abu Talib lovingly wants to explain it in a modern environment. There, the prophet (PBUH) said "O my uncle! By God, if they put the sun in my right hand and the moon in my left on condition that I abandon this course, until God has made me victorious, or I perish therein, I would not abandon it." 28

We see the same persistence in religion in the lives of his companions. Today's young man must demonstrate such a stand on the Islamic ideology as opposed to Western ideas.

2. Tolerance: Islam combines other religions, beliefs, and ideas as a fact despite having a separate identity and being a true religion, but also teaches the doctrine of coexistence while giving full freedom to those who believe in them on religious binary differences and linguistic diversity. Often the wisdom of Allah requires recognition. So Allah Almighty said:

And of His signs is the creation of the heavens and the earth and the diversity of your languages and your colors. Indeed in that are signs for those of knowledge. ${ }^{29}$

The purpose of religious fundamentalism is initiation and challenge, as Allah says:

$$
\text { To each of you, we prescribed a law and a method. }{ }^{30}
$$

Even the bright thinkers of the subcontinent have felt the need for tolerance. The Jewish apartheid philosopher Jacques Derrida not only respects religions with a sincere heart but also gives the true faith the name of Authentic Believer. To him: Only true believers, true Christians, true Muslims (i.e. those who live by religious beliefs wholeheartedly) can have a better understanding of the beliefs of other religions. In his view, meaningful and fruitful dialogue between civilizations can be created in such a case and it is desperately needed in the current cultural crisis." ${ }^{31}$

Being rooted in liberty, being the same superstition, each one having the same blood inheritance, we declare again:" All human beings are brothers, and the value of freedom is mutual tolerance. ${ }^{32}$

For the Muslim youth, it is a matter of pride that the declaration of brotherhood and tolerance, which the intellectuals of the West are 
proclaiming today, Last prophet $(\mathrm{PBUH})$ fourteen hundred years ago, was uttered by these words.

Be servants of Allah as brothers and sisters ${ }^{33}$

When the Prophet (PBUH) emigrated to Medina, he strengthened the society of Medina with two actions.

First of all Holy Prophet (PBUH) established religious relations between Muslims in the form of Mawakhat e Madina. As a result, Ansar shared their wealth and property with refugees.

Secondly, He (PBUH) was reached an agreement between the Muslims and the Jews of Medina, which gave all the citizens of Medina equal rights, and the defense of Medina was the common responsibility of all.

The 38th Annual Convention of the Islamic Society of North America was held July 1 to 4 in 2011 in Chicago. The culture of presenting Islam with the West is taking over the West. The effects of this process can only be positively avoided if a multi-faceted society is accepted. Muslims accept one another over the division of Shia, Sunni, Barelvi, Deobandi and Hanafi Shafi'i in Muslim society. The concept of responsibility is also a reality in Islamic society. Today the facts are complicated, while we live in multi-dimensional societies, we have to re-evaluate traditions in today's context. "34

3. Perseverance: Wholeness is not realized in a moment. Throughout a life time, there must be a constant effort and striving toward self-purification. ${ }^{35}$ As a result of Western global colonialism, materialism has also deprived Muslim youth to the true objective of life. They like to eat, drink and be happy, like the West, and embrace the purpose of life by absorbing Western civilization, young people who are unaware of the purpose of life should worship Allah and obey His Messenger. As Allah says:

I have only created Jinns and men, that they may serve Me. ${ }^{36}$

The Prophet (PBUH) reinforced this belief in the population of the Companions during their five years of life. Today the tune of science, technology, the competitiveness of academic excellence and the pursuit of one another have created an environment in which every young career is engulfed by fanaticism. Islam does not forbid the career and the future to be better, but what forbids the young man's not aware of the true purpose in life.

4. Harmony: Islamic society has a distinct identity unlike other civilizations because of its principles, ideology and socio-economic teachings, so that's why Muslims living in a multi-ethnic society in India (the subcontinent) advocated separate homeland so that they could practice Islam freely. The 
etiquette that Islam has provided opportunities for happiness and sadness is quite the opposite of other religions. Similarly, Islamic festivals have their own unique status. This is why Islam demands its followers to abide by rhetoric and refrain from attending non-Muslim festivals, whose purposes are contrary to the great aims of Islam. ${ }^{37}$

The month of April is a celebration of Christianity called Easter. To them, the status of all religions is the same. They attend Eid simply to please their parents and relatives, but they do not seem to have the affection and interest in their religion, which is part of our faith. ${ }^{38}$

When liberal-minded children reach puberty, they consider religion as a chain in their free life. The offspring born as a result of the incest has nothing to do with religion because of these potential pitfalls, The Prophet (PBUH) decree is mentioned in the history books. 'Do not know the language of the dictionaries and do not enter the participants in their lineage, on the day of their feast, otherwise, the discontent will descend upon them. ${ }^{39}$

As a result, young people living in Western postmodern society need to be aware of the basic teachings of religion. For these young people, the common society, which laid the foundation by Muhammad (PBUH) for peaceful coexistence was the first model of a post-apartheid society. He (PBUH) made a pact with the Jews of this time. It was the first agreement in history regarding civil rights in which Jews were given complete religious freedom, and their defense and protection were taken over. This Agreement contains approximately 52 provisions. The contents of the agreement were religious freedom, protection of rights, protection of life and property, confrontation with the invading enemy, mutual sympathy, the mechanism of resolving the differences, the scope of reconciliation and the powers. Not only did other religions have religious freedom in the post-prophetic society, but the study of the Holy Prophet (PBUH) shows that you have never persuaded non-Muslims to convert to Islam. ${ }^{40}$ Then he abandoned them. ${ }^{41}$

Allah has thought us to seek asylum for the Western Nations in the form of pray" The path of those upon whom You have bestowed favor, not of those who have evoked [ Your ] anger or of those who are astray" in the five-time of day rak'ah, and forbids us from making friends with the Jews and Christians. And whoever is an ally to them among you - then indeed, he is [one] of them. ${ }^{42}$

In this respect, the teachings of the Prophet are very strict. He made this statement strongly regarding the adoption of the practices of non-Muslim 
society. Narrated Abdullah Ibn Umar: The Prophet (PBUH) said: He who copies any people is one of them. ${ }^{43}$

Allah's Messenger (PBUH) as saying: You would tread the same path as was trodden by those before you inch by inch and step by step so much so that if they had entered into the hole of the lizard, you would also follow them in this. We said: Allah's Messenger, do you mean Jews and Christians (by your words)" those before you"? He said: Who else (than those two religious groups)? ${ }^{44}$

In another hadith, the Prophet (PBUH) said, "You will follow the wrong ways, of your predecessors so completely and literally that if they should go into the hole of a mastigure, you too will go there." We said, "O Allah's Messenger (PBUH)! Do you mean the Jews and the Christians?" He replied, "Whom else?" (Meaning, of course, the Jews and the Christians.) ${ }^{45}$

5. Gratitude: Europe has been ruled over most parts of the world, and especially over Islam in the past few centuries. It has been utilized education, the media, and all other resources to reject Western thinking in such a way that no part of the Muslim world could be protected from its influence, so that's why would Muslims living in the West not be affected. In fact, the West has made Muslims a master of such an intellectual mind that in their own eyes, their civilization, nationalism, and ideology have become worthless. The analysis of the mental slavery of Muslims is as follows: "Muslims are backward. Their culture is eroding, they are slowly absorbed in Western civilization. The West is dominating their minds and hearts. Their minds are waning in the West. Their intellectual forces are trained according to Western principles. Their morals, their economy, their society, their politics are being colored in Western life. Their new generations are coming up with the idea that the real law of life is what they are getting from the West."46

Young people must find a sense of the utility and superiority of the religion of Islam by liberating themselves from the imagination of Western civilization. It is necessary for them to get acquainted with this great and glorious historical heritage which tells us what were the golden principles that the Muslims achieved. The Prophet (PBUH) had strengthened the privileges and superiority of the religion in the mind of the Companions; He (PBUH) said to the Companions On the eve of Gazwah e Tabook: "You are the best on the earth." 47 The timely renewal of the task is to restore the founding of the Ummah towards Islam, whose relationship has been left out of this class." One of the greatest worships is to cure the anxiety and psychological confusion in which today's educated youth is badly arrested, and their rationality and academic mind must be fully integrated with Islam. ${ }^{48}$ 
6. Purity: For promoting moral indoctrination in Western societies have a role of their intellectuals and writers. Therefore, English economists, German social democratic party leader Bebel and the British philosopher Mill have encouraged people to cross gender boundaries and offer moral reasoning in support of their position, they argued that marriage was unnecessary and ineffective, while sexual misconduct was an essential requirement. Gradually this trend took over Western society. Muslim youth also came under wraps. Holy Prophet (PBUH) was very focused on the character building of youth. One day a young man from Quraish came to the Prophet (PBUH) and unceremoniously asked him, "O Messenger of Allah!" Allow me to commit adultery, the companions disliked the young man, went on an unconscious act and deserved to be severely punished, but the Messenger of Allah (PBUH) made a unique decision. He called the young man and said: Do you like this thing for your mother? The young man said: My soul is sacrificed to you, I would never like this thing for my mother, Then He (PBUH) asked such questions about his sister, daughter-in-law and his aunt, do you like it for them. He would always say: My soul is sacrificed to you, By God! I could not like this thing. Then He (PBUH) called the young man near him and prayed to Allah for it. After which he was never inclined to this stupid act. ${ }^{49}$

Islam is the stronghold of all the evil that young people suffer in it. Islam strongly urges us to abstain from evil. If we do not avoid evils even though we know the evil and know its consequences, then this blessed statement of the Messenger of Allah should be kept in our mind. "If you have no shame, do what you like". 50

7. Devotion: Young people are the main force in the development and construction of society. Although young people are mentally and physically strong but modern media and technology have had a negative and detrimental effect on their creative abilities. Most of today's young people are just playing games on mobile phones, Facebook and the Internet. Sitting down and keeping a constant eye on the screen is adversely affecting the youth's mental and physical abilities instead of becoming useful citizens to society, they become burdened. The responsibilities and duties of Muslim youth have increased in this cultural conflict in the Middle East. They must work positively and constructively for providing their services to society while reaffirming their creativity so that they can become the embodiment of Islam in Western pluralistic societies and provide a better understanding of Islam for the West. The study of the biography of Prophet (PBUH) shows that the Prophet paid special attention to the mental activity and training of young people. Dr. Mohammad Hamidullah writes in this regard: 
As soon as he arrived in Medina, he made a penthouse in front of his house, which was also called Suffa. It became a Madrassa (rather University) by day, and at night the headquarters and boarding. The apostles used to give divine knowledge but to teach elementary education and writing, the task was entrusted to young volunteers. ${ }^{51}$

Ransom of prisoners of Ghazwa Badar in Mecca decreed that everyone should teach at least ten children in Madina. ${ }^{52}$

Most of the companions were responsible to write the revelation, including Hazrat Ali, Hazrat Amir al-Ma'awiya, Hazrat Abdullah bin Masud and Hazrat Zaid bin Sabat (RAA).

Narrated Anas bin Malik: That the Messenger of Allah (PBUH) said: "The most merciful of my nation is Abu Bakr, and the most severe of them concerning the order of Allah is 'Umar, and the most truly modest of them is 'Uthman bin 'Affan. The best reciter (of the Qur'an) among them is Ubayy bin Ka'b, the most knowledgeable of them concerning (the laws of) inheritance is Zaid bin Thabit, the most knowledgeable of them concerning the lawful and the unlawful commandments is Muadh bin Jabal. Truly, every nation has trustworthy one, and the trustworthy one of this nation is $\mathrm{Abu}$ 'Ubaidah bin Al-Jarrah." 53

When the Holy Prophet (PBUH) saw some of the young companions with personal skills, He (PBUH) gave them an opportunity to develop it so they must be able to provide their services in society. Hazrat Zaid Bin Sabit (RA) was an expert in calculations that is why He (PBUH) called him the expert of the law of inheritance. He (PBUH) also made a special prayer for the memory of Ibn e Abbas (RA). ${ }^{54}$

Narrated Ibn 'Abbas: Once the Prophet embraced me and said, "O Allah! Bestow on him the knowledge of the Book (Qur'an)."55

Hazrat Ali (RA) was also a young companion. The Prophet (PBUH) sent him as Judge of Yemen and prayed on his behalf: "May Allah guide his tongue and persevere his heart." 56

So the prayer of the Holy Prophet (PBUH) was accepted and he was inculcated with these attributes. ${ }^{57}$

In addition, to enhance mental abilities, $\mathrm{He}(\mathrm{PBUH})$ focused on the physical training of young people. He (PBUH) himself learned swimming at an early age. ${ }^{58}$ 
Holy Prophet (PBUH) also remained interested in the art of wrestling. The Rak'ana event of wrestling is a famous one in the history of wrestling. In the race, the most popular was the race of men, horses, donkeys, and camels. He (PBUH) used to reward winners. Separate distances were allocated for trained and unskilled horses. Those places are still preserved in Medina from where the horses of the betel were used to start the race, also the place where $\mathrm{He}(\mathrm{PBUH})$ stands and determines the winners. There is now a Mosque alSabaq (Mosque for the race) at this location.

Allama Ibn Al-Qa'yyim mentioned in his book al-Faroosiya that in addition to competition in things, also contradicts the lifting of the weaving stones during the time period of Prophet (PBU). ${ }^{59}$

8. Services: The Holy Prophet (PBUH) appointed an intelligent young man as the leader of his tribe. In fact, the standard was that who is more familiar with Islamic principles of divination? These attributes are commonly found in young people. One of the companions, Salma Al-Jarmi (RA), states that when I became a Muslim with my family, I was very young, but because of the abundance of Qur'anic Sur' ah, I was appointed as the leader of my tribe. ${ }^{60}$

Other important tasks were often entrusted to the youth. For example, $\mathrm{He}(\mathrm{PBUH})$ appointed Osama Bin Zayed (RA) as a military commander at just seventeen years old. ${ }^{61}$

In the battle of Khyber, Hazrat Ali (RA) will be hardly twenty-five years old. He was appointed as a very important officer. ${ }^{62}$

In later years he was also appointed governor and judge. ${ }^{63}$

Hazrat Umar bin Hazm and Hazrat Muadh bin Jabal (RAA) were also very young companions. He (PBUH) was made the governor and inspector general of Education of Al Yemeni province, respectively. ${ }^{64}$

Regarding Hazrat Muadh (RA), Al-Tabari writes that his work was to unite villages and districts and to supervise and arrange education there. ${ }^{65}$

According to Dr. Hamidullah: "Where many generalities were established for the administration and politics at Aden, along with the internal system of cities and tribes was also fixed. Every ten people in every locality of every village or city were appointed a representative. Had a protector who was directly responsible to the governor and the rulers of the cause were also imposed through it. The men had to get the opinion that this was done by the representative while watching representative work, which was usually given 
to young people, and they performed their duties with care and speed. According to the release of thousands of Hawazan prisoners, many people were asked gradually by representatives and then came to Muhammad (PBUH) for the decision. ${ }^{66}$

He writes:" There was no shortage of applause and awards for young people for encouragement. And it is only by focusing on the talent of the youth that is the secret of the nation that has never heard from this nation since its first Islamic Government establishment in fifteen to twenty years. When it goes to three continents, it must able to provide good commanders and officers on whom humanity can be proud. ${ }^{67}$

\section{Conclusion}

Although Muslims face many problems in Western postmodern societies, it is difficult to live there, especially because of linguistic, ethnic and religious prejudices. In these situations, Muslims have a responsibility to fulfill their position by practicing the right direction and reasserting their intellectual ability. Therefore, they should play a vital role in various fields of social, political and economic life. As Muslims have participated in political activity constantly in the present era in the United States and Britain, the success of two Muslim women Rashida Talib and Ilhan Omar has added a new history in the midterm elections of the United States. This is what the study of the Seer'ah of Prophet (PBUH) says that the Prophet (PBUH) prepared Muslims for leadership. As a result, most of the work He (PBUH) does was entrusted to the young Muslims. Many of his ideas are found in books of Seer'ah and history of Islamic inheritance. Thus, when a tribe converted to Islam, the Holy Prophet (PBUH) appointed an intelligent young man as its leader. In fact, the standard was that who is more familiar with Islamic principles of divination? These attributes are commonly found in young Muslims of that time and they contributed to the development of Islam in Arab's multi-dimensional society which is a legacy for today's Muslims.

\section{Recommendations}

1. The Muslims of modern times must develop their mental and physical abilities in the light of the golden principles of Seer'ah of Holy Prophet (PBUH) so they can play their leading role to society.

2. Muslims must have skills to understand Islamic Principles based on the Qur'an and Hadith to provide the model of excellence in the present era. 


\section{Endnotes}

1 Sarwat Sulat, Dunya mein Muslim Aqliatien (Karachi: Idara Maraif e Islami, 1990) 2/47

2 Musa Khan Jalal Zai, Musalman Aqliatien charun briazmun mein (Lahore: Students Services the Mall road, 1993), 170-171

3 https://www. The guardian. Com, Religion: why faith is, becoming more and more popular by Harriet Sherwood Monday, 27 August 2018.

4 Michael Quinlan, The great divide where religion beliefs and the I am meet, university of Notre Dame Australia, the conversation. com, August 24, 2017.

5 James Burnham, Suicide of the West: An Essay on the Meaning and Destiny of Liberalism,(New york, Library of Congress, 2014).

7 Kitani, Dr. Europe and American Muslims, from the book of Sarwat Sulat, Duniya mein Muslim Aqliatien, (Karachi: Daira Maarif Islami, 1990) $1 / 18$.

8 Masood Abdali, America mein Islamophobia aur Tashadud ki Lehar (Karachi:Roznama Ummat, August 10, 2012) P: 10.

9 Iftikhar Gillani, Azadi Raye, Magrabi Tazadat aur Mulim (Tarjuman ul Qur'an, November, 2018).

${ }_{10}$ Daily Nawa e Waqat, July 4, 2016, P 3.

${ }^{11}$ Ramzan Asfar, Muslmano ky Khilaf Nafrat Angez Jarim mein Izafa (Haft Roza Nidai Millat, 8 to 24 Oct 2015) V, 9, Issue 5, Page 33.

12 http:waqatnews.tv.04.01.2013.

13 Ramzan Asfar, Muslmano ky Khilaf Nafrat Angaiz Jarim mein Izafa (Haft Roza Nidaie Millat, 8 to 24 Oct 2015) V: 9, Issue 5, Page 33.

14 Syed Abul Hassan Nadavi,Nai Dunyia America mein saaf saa baatien (Karachi, Majlis e Nashriyat Islam, ND), P: 96.

$15 \mathrm{http}: / /$ Express.PK/Story,21.11.2015.

16 Iftikhar Gillani, Bharti Muslman:Siasi wa Samaji cusumpursi (Mahanama Tarjuman ul Qur'an, December 2018)

17 Tama'ar Nisar, Israel mein Nasal Parasti ka kanoon aur Natiaj (Tarjuman ul Qur'an, August 2018).

${ }^{18}$ HsinYi Lo, A Multi- faith Society. The path way to Harmony, February 2013, right now.Org.au

$19 \mathrm{http}: / /$ www.Express.Pk/story, 21/ 11/ 2015.

${ }^{20} \mathrm{http}: / /$ vigarehind.com 
21 Muhammad Sadiq Shah Bukahri, Rawadari Aur Maghrib (Lahore, Ilm o Irfan Publisher, 1999), P 276.

22 Tayyaba Zia Cheema, September 11( Lahore: New book palace, ND), P: 13 .

23 Ibid: 170.

24 http://viqavehind.com

25 Surah Fussilat, 41:30.

26 Al-Qushayrī an-Naysābūrī,Muslim ibn al-Hajjāj ibn Muslim ibn Ward ibn Kawshān, Sahih Muslim (Beirut: Dar ul Fikar, ND), The Book of Faith,(13)Chapter: A phrase that sums up Islam, Haith, NO 38is.

27 Nadvi, Abul Hassan, Nai Duniya America mein Saf Saf Batien (Karachi, Majlis e Nashriat, ND) Page 96.

28 Ibn e Kathir,Al bidayah wan nihaya( Beirut:Dar Ibn e Kathir,1990), P: 1833.

Muhammad Ali Al Saba, Beina Yad ul Yameni wa Yad ul Yusra, (Shabka Al Wuqa, Afaq ul Sharia,2017), 22948.

29 Ar Room, 30:22.

30 Al-Ma idah, 5:48.

31 Dr. Tahsin Firaqi, Insaniyat Fasad aur Sulah ky Dorhy Per (December 2018).

32 Ibid.

33 Bukhari, Muhammad bin Ismael, Al-Adab Al-Mufrad, Al Jame Al Adab Al Nabwia, (Saudia, Dar ul Sadiq, 2nd Edition, 1441) Chapter: Separating oneself from Muslims, 398.

Al Qashari, Muslim bin Hajaj, Sahih Muslim, The Book of Righteousness, Relationship, and Ethics, The door to the prohibition of incitement, hatred and measures, 2559.

Bukhari, Șaḥīh al-Bukhārī, (Beirut: Dar Ibn e Kathir, 1990), Book of Ethics, Chapter, what is forbidden from envy and measures 5718.

34 Maqbool Ahmad Siraj, 48 the Annual ISNA convention at Chicago Pluralism will be the challenge of 21 st Century, Radiance views weekly, 17 July 2011, radiance weekly. In portugal archive.

35 Dr. Naji Ibrahim Arfaj, Have you Discovered its real Beauty in an aqueduct, P: 13, https: //www. Goodreads .com.

36 Surah Al Zariyat, 51:56.

37 HSIN Yi Lo, A Multi-Faith Society: The pathway to Harmony, right now.org.au, February 2013.

38 Monthly Sira't e Mustaqim Birmingham, 2001, P-4.

39 Ibn e Taimia, Ahmad bin Al Haleem, Iqtaza Al Sirat Al Mustaqim (Beirut: Dar e Alam Al Kutab Al Arabia, 1999), 1/511. 
40 Surah Al Baqarah, 2:256.

${ }^{41}$ Qazi Sanaullah Pani Pati, Tafseer Al Mazhari (Beirut: Dar e Ihia Al Turas ul Arabi,2004)1/398.

42 Surah Maida, 5:51.

43 Abi Dawud, Suleman bin Ashas, SUNAN ABU DAWUD, Clothing (Beirut:Dar ul Hadith, 1969), Kitab Al-Libas,Chapter: A Garment of Fame and Vanity. Hadith No:4031.

44 Al Qashari, Muslim bin Hajjaj, Sahih Muslim, The Book of Knowledge, Chapter: Following The Ways of the Jews And Christians, Hadith No, 2669.

45 Bukhari, Sahih Bukahri, Chapter:Prophets, What has been said about Bani Israel, 3456.

46 Maududi, Syed, Islami Tahzeeb (Tarjuman Al Qur'an, October, 1935).

47 Bukhari, Sahih Bukhari, THE BOOK OF AL- MAGHAZI, HADITH NO. 4154.

Ibn e Kathir, Ismail Bin Umer Abul Fida,Al Badaya wal Nahaiya (Dar ul Fikar 1986) 4/171.

48 Nadvi, Abul Hassan Ali Hassani, Naya Tufan Aur Iska Muqabala (Lakhnu: Majlis e Tahqiqat wa Nashriat Islam, Edition 3, 2009), 29.

49 Ahmed bin Hanbal, Musnad, (Macca: Maktaba Dar ul Baz, 1993), 22211.

50 Abi Dawud, Sunan Abi Dawud,General Behavior (Kitab Al-Adab), Hadith No, 4797.

51 Dr. Muhammad Hamidullah, Ehad e Nabvi (PBUH) mein Nizam e Hukmarani (Karachi: Urdu Academy, 1987) P. 291.

52 Al Zuhri,Muhammad bin Saad, Al Tabaqat ul Kubra ( Beirut: Dar e Ihia Arabi,19996), 2/260.

53 Tirmazi,Abi Issa Muhammad bin Issa bin Sura, Jame Sahih( Beirut: Dar e Imran, ND), Book of Al-Manaqib (Virtues), Hadith No 3791.

54 Ahmed, Musnad, 3024.

55 Bukhari,Sahih al-Bukhari,Book of Knowledge, Hadith no, 75.

56 Al Zuhri, Muhammad bin Saad bin Muni, Tabaqat ul Kubra (Leiden,1321), 2:337.

57 Abdul Hai, Al Kitaei, Al Tararib ul Idaria, al Musama bi Nizam Al Hakumia al Nabvia, (Beirut: Dar Ihia Al Turas al Arabi, ND) 1/56, 2/239,314,315.

58 Ibn e Qayyim, Al Jawzeya, Muhammad bin Abi Baker, Al Faroosia (Saudi Arabia: Researcher Mashoor bin Hassan bin Mahmood, Dar ul Undlas, 1993), 1/ 86-87. 
59 Ibid.

60 Dr. Muhammad Hamidullah, An Hazrat (SAW) Ka Nujawanon ki Sath Salook (Dunya Newspaper, Daily, September 12,2012), Special feature.

61 bn e Hisham, Al Seerah Al Nabwia ( Cario: Mustafa Al Babi Al Halbi Wa Uladuhu, 1995), 2/606, 641.

62 Tabri, Ibn e Jareer, Tareekh e Al Rasool Wa Malook (Beirut: Dar ul Turas $1387 \mathrm{AH}), 3 /$ 12-13.

63 Al; Qurtubi, Muhammad Bin Abdul Bar, Al Istiab FiL Muarfat al Ashab ( Macca Al Mukarma, ND), 3/460.

64 Dr. Muhammad Hamidullah, An Hazrat (SAW) Ka Nujwanun ki Saath Salook (Dunya Newspaper, Daily, September 12,2012), Special feature.

65 Tabri, Ibn e Jareer, Tareekh e Al Rasool Wa Malook 2/288.

66 Dr Hamidullah, Ehad e Nabvi mein Nizam e Hukmarani, P 293.

67 Ibid. 